\title{
Into the future: Donkergat Military Training Area and the Langebaan Ramsar site
}

\begin{abstract}
Authors:
Jan T. Marx ${ }^{1}$

lan Liebenberg ${ }^{2}$ (1)

Affiliations:

${ }^{1}$ Department of Geography and Environmental Studies, Stellenbosch University,

South Africa

${ }^{2}$ Centre for Military Studies and Faculty of Military Science, University of Stellenbosch, South Africa

Corresponding author: lan Liebenberg, jankalahari@gmail.com

Dates:

Received: 22 Apr. 2018

Accepted: 12 Oct. 2018

Published: 26 Feb. 2019

How to cite this article: Marx, J.T. \& Liebenberg, I., 2019, 'Into the future: Donkergat Military Training Area and the Langebaan Ramsar site', The Journal for Transdisciplinary Research in Southern Africa 15(1), a566. https://doi.org/10.4102/ td.v15i1.566
\end{abstract}

\section{Copyright:}

(C) 2019. The Authors. Licensee: AOSIS. This work is licensed under the Creative Commons Attribution License.

Read online:
Militaries need natural areas for offensive and defensive combat-readiness programmes. Here soldiers, war machinery and munitions are employed to prepare forces to execute warfighting tactics. Integration of environmental considerations into military activities is a growing global challenge. This study is based on a qualitative approach underpinned by an extensive literature review. The potential for the contribution of the military to a sensitive and diminishing wetland on the West Coast of South Africa (SA) is addressed. Donkergat Military Training Area (DMTA) in the Western Cape province, SA, provides diverse, seaborne training and warfighting facilities for the South African Special Forces (SASF), a specialist branch of the South African National Defence Force (SANDF). This facility borders the Atlantic Ocean and Langebaan Lagoon, a Ramsar site (no. 398). One of only 15 island ecosystems on the southern African coastline, lies within the boundaries of the area. Saldanha Bay was identified as an economic development node by the national government. The 4 Special Forces Regiment (4 SFR) is thus obliged to contribute to the conservation of these environmental assets. Industrial development includes Operation Phakisa by the Department of Agriculture, Forestry and Fisheries (DAFF) that envisages expanded aquaculture practices in Saldanha Bay. Developers of fish and bivalve farms are allowed up-scaling aquaculture operations. These result in the loss of ecological attributes of the Langebaan Lagoon Wetland system. In the study, we recommend that parts of DMTA should be incorporated in the Ramsar definition for the Langebaan Lagoon Wetland system. Ecosystem indicators monitoring bird life, water and sediment quality, fish and rocky intertidal macrofauna in the DMTA waters should be intensified. The DMTA as a benchmark ecosystem in the Saldanha Bay area will facilitate environmentally sound planning amidst recent developments. Integrating sections of the Langebaan Lagoon that is part of the DMTA into the existing internationally recognised wetland area, the military can contribute significantly to wetland conservation. Management of these areas should be formulated in a Military Integrated Environmental Management (MIEM) plan by incorporating international guidelines.

\section{Introduction}

The military of any country needs natural areas for combat-readiness programmes where tactics in warfighting endeavours are rehearsed. The integration of environmental considerations into military activities is a growing global challenge, and in this study the possibility for the contribution of the military to a sensitive and diminishing wetland on the West Coast of SA is addressed.

A consideration of MIEM for South African National Defence Force (SANDF) properties, including DMTA, requires reflection on international environmental laws. South Africa has signed and ratified virtually all the current environmental conventions and protocols (South Africa 2001), and in cases, even played a leading role in the implementation and development of these international legal agreements. One important agreement that SA has ratified is the Convention on Wetlands of International Importance especially as Waterfowl Habitat (Ramsar Convention). ${ }^{1}$ According to the criteria of the Ramsar Convention (established 1971), there are presently 23 wetlands of international importance in SA (Ramsar Sites Information Service 2017). ${ }^{2}$ Langebaan Lagoon in the Western Cape

1.Some other important agreements that South Africa has ratified and that are applicable to a military area such as DMTA are the Bonn Convention on Migratory Species (CMS), the Convention on Biological Diversity (CBD) and the UNESCO World Heritage Convention (WHC). Additional international conventions, treaties, agreements and protocols relating to the core business and the environmental responsibility of the DOD are listed in South Africa (2001). These agreements form part of international law and have limited application in South Africa if not ratified by parliament, formulated in other legal imperatives and applied during assessments (DEAT 2005; World Bank 1996). The above relates closely to the drafting, implementation and monitoring of MIEM plans as discussed here.

2.Other Ramsar designated wetlands in the Western Cape are the Bot - Kleinmond Estuarine System (1349 ha), De Hoop Vlei (750 ha), De Mond (918 ha), False Bay Nature Reserve (1542 ha), Verlorenvlei (1500 ha) and Wilderness Lakes (1300 ha). The Western Cape hosts the most estuarine wetlands but in KwaZulu-Natal Kosi Bay (10 $982 \mathrm{ha}$ ) and the St. Lucia System (155 500 ha) also fall in this category. Last mentioned designated on 02 October 1986, was downgraded and added to the Montreux Record on 04 July 1990 but 6 years later on 11 March 1996 received its elite status back (The Montreux Record 2011). There is already islands included in the Ramsar List and site number 1688 is the Prince Edward Islands ( 37500 ha) also falling under the Western Cape Province (Ramsar Sites Information Service 2017). In other provinces some wetlands designated of international importance have been shamefully downgraded and is included in the Montreux Record with no re-classification yet. These wetlands are Blesbokspruit in Gauteng and Orange River Mouth in Northern Cape. 


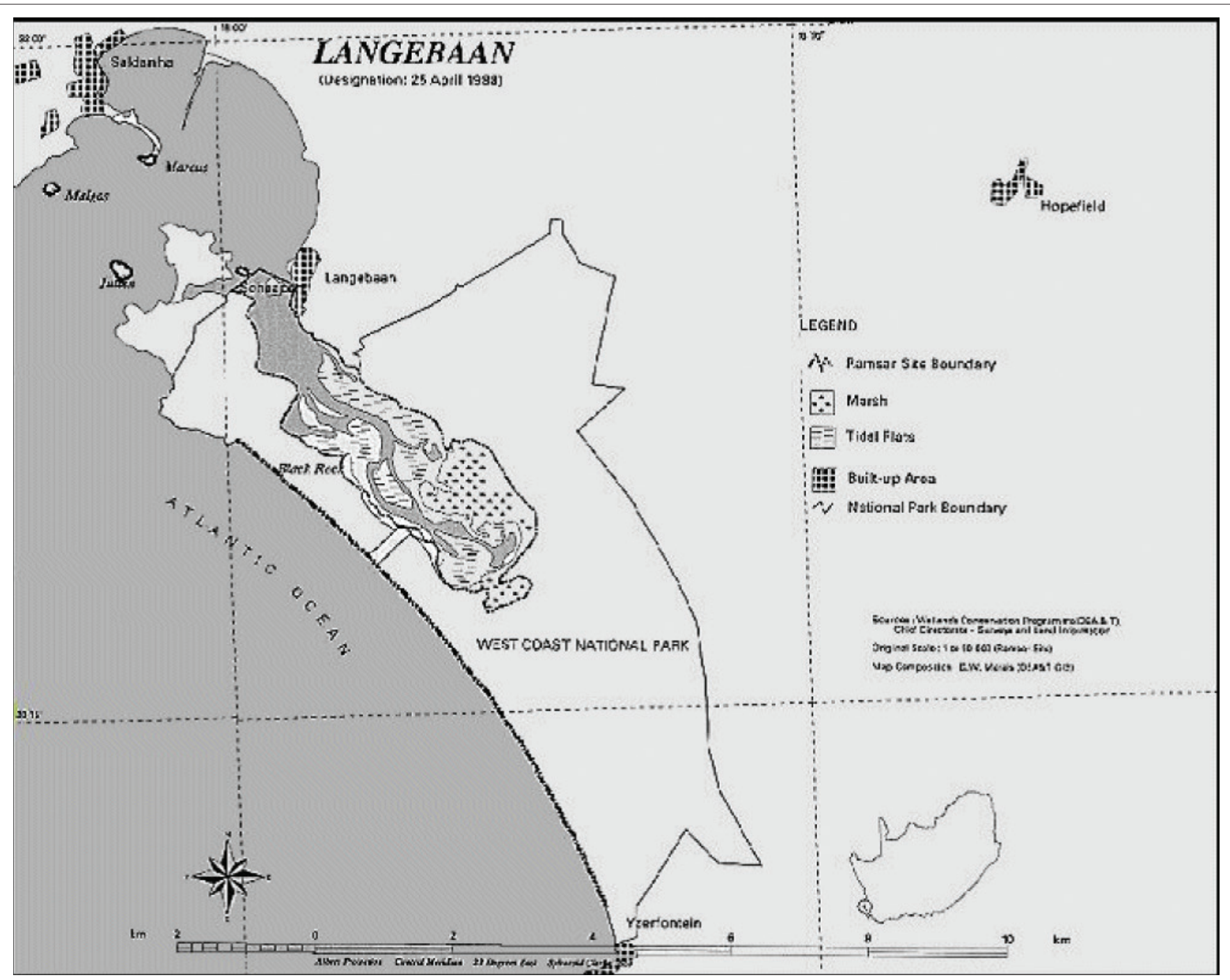

Source: De Graaff, G. \& Randall, R., 1987, Langebaan Lagoon Ramsar Designation, National Parks Board of Trusters, Pretoria, viewed 30 August 2017, from https://rsis.ramsar.org/398 FIGURE 1: Original map of the designated Langebaan Ramsar wetland area.

province was designated to this list (no. 398) on 25 April 1988 (Cowan 1995), with the following depiction:

The designated site is composed of the islands Malgas, Jutten, Marcus and Schaapen; Langebaan lagoon (15 km long, 12,5 $\mathrm{km}$ wide) up to the high-water mark, including marshlands and precincts of the lagoon, and a section of Sixteen-mile beach. (p. 16)

The initial map with the allocated border of the Ramsar site was drafted by De Graaff and Randall (1987) and is shown in Figure 1.

The first conservation measures aimed specifically at the Langebaan Lagoon were implemented in 1973 when this water system up to its high-water mark was proclaimed a reserve in terms of the Sea Fisheries Act. The Postberg/Oude Post Nature Reserve, that neighbours the lagoon, was proclaimed a private nature reserve in 1969 and is owned by a company that was previously known as 'Die Oude Post Sindikaat' Pty Ltd. Postberg/Oude Post Nature Reserve is still presently owned by a number of influential individuals that own properties on this 1851 hectare (ha) of pristine land. Adjacent to Postberg is the West Coast National Park (WCNP) that was proclaimed on 30 August 1985 (Government Gazette 9904 1985) and is managed by the South African National Parks (SANParks). In August 1987, Postberg was included into the WCNP (Government Gazette 10789 1987), the first contractual national park in SA. Situated next to Postberg Nature Reserve is a SANDF asset, namely the DMTA, an exclusive South African Special Forces (SF) base (see Figure 6).

\section{The military training area}

Donkergat Military Training Area originated from a need identified for a seaborne unit when SF started executing transborder operations in southern Africa. The first SF base in SA, namely 1 Reconnaissance Commando, was established at the Bluff in Durban where a whaling station, initiated by a Norwegian Johan Bryde, was operational from 1908 to 1953 (Best \& Ross 1989). The same Johan Bryde built a whaling station at Donkergat that commenced with operations in 1909 and closed down in 1967 because of an international ban 
on whale hunting ${ }^{3}$ (Best \& Ross 1989). In 1972, during the South Africa-Angolan war, the first SF waterborne operation was launched from the Bluff, resulting in the founding of C Group, a water-orientated specialist grouping (sometimes referred to as 'sea recces') in 1975/1976.

The need for a seaborne unit was recognised and subsequent to a detailed search around the coast of SA, the Donkergat area was identified, because it is secluded and easily accessible by naval vessels. In 1978, the peninsula was allocated to the then South African Army (SAA) and 4 Reconnaissance Commando, now 4 SFR, came into being (South Africa 1979a). Donkergat Military Training Area, bordering sections of the Langebaan Lagoon, was thus inaugurated as a SF seaborne facility 10 years before the Langebaan Lagoon obtained its international status. More land, including Riet Bay (South Africa 1979b), was later added and the area that the DMTA covers today was proclaimed (Figure 6 shows the contemporary boundaries of DMTA). In the same way that Donkergat Bay and Salamander Bay provided safe anchorage to ships during the whaling era and to flying boats during the Second World War (Spring 1995), these havens are ideal for accommodating the variety of seaborne activities required from 4 SFR today. ${ }^{4}$

The DMTA hosts diverse preparations and rehearsals for national and foreign operations that comprise demolitions, shooting, parachuting, urban exercises, boating, surface swimming, survival, mountaineering and diving. The training area covers a terrestrial area of 1384 ha, with the borders stretching over waters of the Atlantic Ocean and Langebaan Lagoon. Meeuw Island, one of only 15 island ecosystems surrounding SA, is enclosed in the military area.

As can be seen from Figure 1, the border of the proclaimed Ramsar area stretches from Perlemoen Point, south of Riet Bay, to Leentjiesklip in Langebaan, excluding the military area (Figure 6). It is suggested that the present formulation of the wetland as described by Cowan (1995) should be revised and specifically Meeuw Island and Donkergat Bay, Riet Bay and Salamander Bay should be so denoted. To include the island and bays, the Ramsar area border should stretch from Salamander Point north of Salamander Bay to Leentjiesklip (Figure 6).

\section{Methodology}

Based on previous academic work conducted in this particular area (Marx 2014), the article intends to inspire research possibilities for future studies. The study is both descriptive and exploratory in nature (Mouton \& Marais

3.The Donkergat Whaling Station was operational from 1909-1920, 1922-1930, 1936 1937, 1947-1953 and 1957-1967. Up to 1967 when the station finally closed, the region's whaling concerns had killed about 100000 whales, including 10600 sperm (Physeter macrocephalus), 10000 fin (Balaenoptera physalus), 69300 sei (Balaenoptera borealis) and 6600 blue (Balaenoptera musculus) whales (Best \& Ross 1989).

4.For more detail on the history of whaling in Saldanha Bay, consult Best (2009). The Whalers of Saldanha, pp. 129, 130 and Marx (2009:135). During World War II Catalina flying boats were also stationed at Langebaan for patrolling purposes, among others, to guard against German submarines that threatened Allied shippin convoys (McLean 2009:145).
1996:43-46). It was undertaken against the broad theoretical framework of functionalism as a research approach. ${ }^{5}$ The literature review made use of general and scientific literature relevant to the DMTA, providing important background. Literature on existing administrative, historical, ecological and military use of the DMTA was explored and, among other, a number of published sources between 1974 and 2016 were utilised. Secondary sources as well as scientific publications were consulted, giving the project a transdisciplinary and interdisciplinary character.

By comparing the National Environmental Management Act (NEMA) (South Africa 1998), principles and regulations with the state of affairs of DMTA, specific environmentally detrimental, inherited ecological disturbances and ongoing military activities with negative effects were identified.

The current exclusion of sensitive areas where birds concentrate and invertebrates flourish in the Langebaan Lagoon Wetland definition was identified as a serious shortcoming.

The chosen research approach also reflects a qualitative angle. In the course of the research, the question arose whether mitigation measures could be implemented to lessen existing impacts of (potentially serious) environmental challenges. Where needed, specialists from Cape Nature, IZIKO Museum, the Regional Facilities Interface Manager (RFIM), the South African Heritage Resource Agency (SAHRA), the Council of Geoscience and other organisations were consulted. Legislation and legal compliance were taken note of where applicable; among others, these investigations related to identifying harmful impacts on the environment chosen for this study. Inclusion of areas of the DMTA in the existing Ramsar definition was investigated. Recommendations flowing from the research process and findings were identified as possible feasible and cost-effective mitigation measures to reduce the negative environmental impact identified in the field of study.

\section{Research question}

The military of any country, including South Africa (SA), needs natural areas for training of offensive and defensive combat-readiness programmes. On these 'sacrificed' areas, soldiers, war machinery and munitions are employed to prepare forces to execute their core function, that is, warfighting. The present focus on environmental issues is a global concern and the integration of environmental considerations into military activities is a growing global challenge. In this case, a research question that addresses the dilemma of the contribution of the military presence to a sensitive and diminishing wetland on the West Coast arises. 5.This article moves beyond the conservation discourse. Since 'ecology' as term that has been coined by the zoologist Ernst Haeckel, much has changed. The notion of ecologism entered the discourse; to see nature as an interconnected whole, embracing the human animal and non-human animal, as well as the inanimate world, thus habitus in its broadest sense (Heywood 2007:277). Environmental ethics likewise plays a role (Heywood 2007:268). Ecologism itself is linked to an awareness of a looming crisis for both nature and human as espoused by Murray awareness of a looming crisis for both nature and human as espoused by Murray Bookchin (see Heywood 2007:277). Sustainability was once used as part of the discourse but is now seen as an axiom. The authors, however, do not deploy (radical) critical theory here and hence this article finds itself in the realm of what some would describe as 'shallow ecology' or environmentalism and not within the theoretical paradigm of 'deep ecology' (Heywood 2007:255ff 257, 259). The article does hold some elements of, or pointers to, the environmental debate or what Leon Baradat calls, environmentalism (Baradat 2012). 
The above discussion appeals to the obligation of the 4 Special Forces Regiment (4SFR) to contribute to the conservation of this delicate wetland system of international importance, especially in view of the growing industrial threat in the greater Saldanha Bay. One of these industrial threats, the proposed projects of expanded aquaculture practices in Saldanha Bay, is a matter of concern for the long-term ecological equilibrium of Saldanha Bay and the Langebaan Lagoon Wetland system. Can the military contribute significantly to the conservation of the wetland by incorporating sections of the lagoon that is part of the Donkergat Military Training Area (DMTA) perimeter into the existing internationally recognised wetland area? If so, management of these areas can be formulated in a Military Integrated Environmental Management (MIEM) plan by incorporating internationally accepted guidelines.

\section{Ecological importance of the Langebaan Lagoon}

On a national level, the conservation of the Langebaan Lagoon and the salt marshes up to its southern extreme is of utmost importance. The area is unique in that no river feeds them and at some 5700 ha the lagoon and marshes are by far the largest in SA, constituting $32 \%$ of salt marsh habitats in the country (O'Callaghan 1990). Langebaan Lagoon is adjoined by 32000 ha of the state-protected WCNP, creating an extensive area of biodiversity in the region. The Lagoon is an inseparable part of the greater Saldanha Bay marine system and supports up to 55000 water birds in summer, most of which are waders that include regular Palaearctic migrants. To the north of the Lagoon lie five islands that host nearly a quarter of a million sea birds, many of which are endemic to the nearshore regions of SA and Namibia. The salt marshes and reed beds occurring in the Lagoon act as essential filtration systems and provide nurseries for numerous endemic fish species. In 2011, wetlands were identified by the National Biodiversity Assessment (NBA) as the most threatened ecosystem in SA and that conservation and management of these systems should be a priority (Department of Environmental Affairs 2012).

\section{Challenges and looming threats}

In contrast with the waters included within the borders of the DMTA, the Langebaan Lagoon is accessible by the public and subject to activities such as water sport, fishing and lately proposals to intensify aquaculture practices in Saldanha Bay. Pressures of recreational and industrial development undertakings are increasing, as Langebaan is becoming a kite and windsurfing mecca, and Saldanha Bay has been identified as an economic development node by the national government. ${ }^{6}$ Industrial ventures are poised (and have started) to commence. Around Saldanha Bay Transnet industrial projects started already with major

6.The South African National Development Plan (NDP) was implemented in 2011 and as national plan aims to enhance the socio-economic situation in South Africa. As an and addressing economic and growth challenges (Consult Mulaudzi \& Liebenberg 2017). The plan affects both government and governance on all levels, namely national, $2017)$. The plan affects both government and governance on all levels, namely national,
provincial and local. This article, especially where industrial developments around provincial and local. This article, especially where industrial devel
Saldanha Bay are concerned, should be seen against this background. upgrades to the General Maintenance Quay and Rock Quay in Saldanha. ${ }^{7}$ Transnet has also projected a Phase 2 expansion of the Iron Ore Terminal (Big Bay side) to increase its holding capacity. The latter activity will require sediment dredging and removal of hard material to make the channel more accessible near the proposed berth. According to Clark et al. (2016), this movement of sediment has the potential to lead to negative side effects for the surrounding environment over the long term.

Further proposed developments include infrastructure to supply Eskom and the industry with additional electricity in the form of a Floating Power Plant (FPP), Liquefied Natural Gas (LNG) Import Facilities and a Gas-fired Independent Power Plant. Additional possible industrial developments that are earmarked include the Elandsfontein Phosphate Mine and Transnet National Port Authority (TNPA) projects, that is, a Vessel Repair Facility, Mossgas Jetty and a Floating Dry Dock (Clark et al. 2016). Figures 2 and 3 show the current layout of Saldanha Bay and that what is planned for the medium term up to 2044 .

A more detailed outlay of the areas proposed for aquaculture farming nearest to the Ramsar area is shown for Big BayNorth of Mykonos and Big Bay-South of Mykonos in Figures 4 and 5 .

The industrial development aquaculture practices in Saldanha Bay will expand significantly (Figure 3). A Basic Assessment Report (BAR) for this venture (DEA Project Number: $14 / 12 / 16 / 3 / 3 / 1 / 1728$ ) was compiled by SRK Consulting and submitted in August 2017 to the National Department of Environmental Affairs (DEA), as well as to DAFF (SRK Consulting 2017). Authorisation was granted on 08 January 2018 by the DEA. In addition, the Southern Cross salmon production facility was also authorised on 08 January 2018, and during July 2017, a BAR for a private enterprise, namely the Molapong Aquaculture Project Saldanha Bay (DEA \& DP Ref Number: 16/3/3/1/F4/17/3014/17), was submitted by Ecosense Consultants (Ecosense Consultants 2017).

The aquaculture ventures shown in Figures 3, 4 and 5 (CapMarine 2016) planned for Saldanha Bay have the potential to influence the delicate balance in the Langebaan Wetland system. It is generally acknowledged that intensive development of the aquaculture industry is accompanied by an increase in environmental impacts (Ervik et al. 1997). From this perspective, the sustainability of intensive marine aquaculture near the Langebaan Wetland system is brought into question. The development of marine aquaculture has led to conflicting demands for coastal resources and it is

7.Current developments include investments in the Saldanha Bay Industria Development Zone (SBIDZ). Projects currently completed or in the construction phase amount to R4.5 billion (2015-2018). These include an Onshore Supply base (OSB), of which eventually three structures will be built, which will include a Marine Engineering Services Hub for oil rigs, support vessels and other services needed. Engineering Services Hub for oil rigs, support vessels and other services needed. The current Liquid Petroleum Gas (LPG) construction programme will involve three escalating phases. Sunrise Energy claims that it will become the largest open access import and storage facility on the African continent. A multi-buoy anchor point and sea and overland pipelines form part of this construction plan which would eventually bring about an annual flow of 200000 metric tonnes (Weslander 28 September 2017a:7, and 2017b:3,). In the research here the potential ecological challenges and threats of such development need to be kept in mind. 


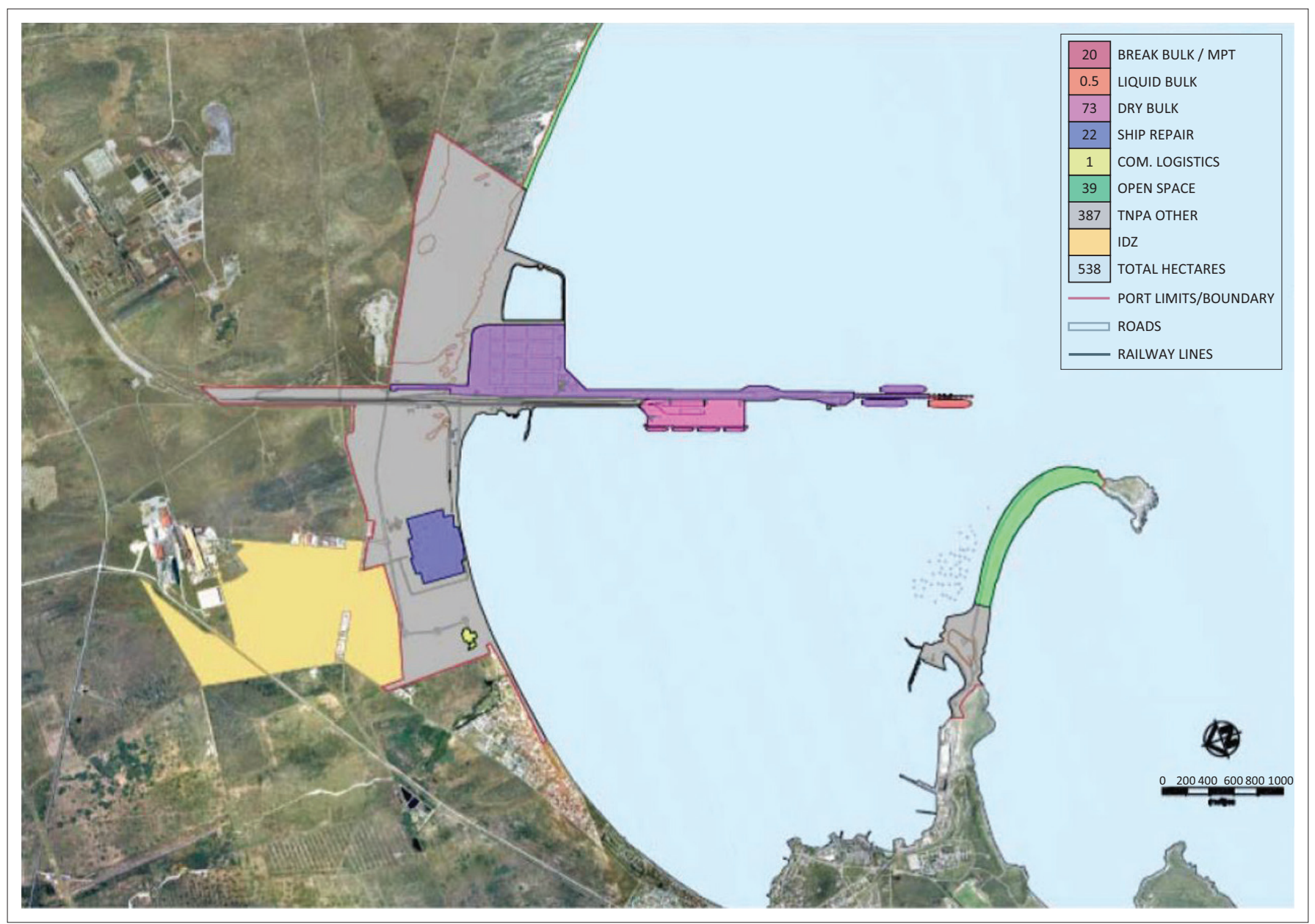

Source: 'Sunrise Energy: 'n Nuwe Era', Weslander, 28 September, 2017b, p. 3

FIGURE 2: Current layout of Transnet Saldanha Bay Port.

widely accepted that coastal aquaculture should be developed within an Integrated Coastal Zone Management (ICZM) framework (Fernandes \& Read 2001; GESAMP (IMO/ FAO/UNESCO-IOC/WMO/WHO/IAEA/UN/UNEP Joint Group of Experts on the Scientific Aspects of Marine Environmental Protection 2001).

It is clear from the above figures that the foreseen developments should take place over the next 5 years and thereafter the broad coastal and wetland environment and habitat will see substantial changes in favour of industrial and other profit-making ventures. The development of the Saldanha Bay port has significantly altered the physical structure and hydrodynamics of the bay, whilst all developments within the area (industrial, residential, tourism, etc.) have the potential to negatively impact ecosystem health. ${ }^{8}$ With the industrial developments around the lagoon and recreational activities increasing, the pressure

8.The article had to take note of further developments such as Operation Phakisa and the Marine Spatial Planning Bill, 2017. South Africa's ocean jurisdiction including the continental shelf translates into an Exclusive Economic Zone (EEZ) of 1.5 million square kilometres. Land size accounts for 1.2 million square kilometres. In Maritime square kilometres. Land size accounts for 1.2 million square kilometres. In Maritime
Spatial Planning (MSP) the new bill makes a distinction between (more) economically important areas such as oil and gas deposits, fishing grounds, transportation routes and other exploitable deposits. The MSP Bill 2017 acknowledges that habitats and species should be protected, reduced fishing and no-take areas should be facilitated and high risk activities such as mining should be controlled (Briefing on the Marine Spatial Bill, 2017 and activities of the Portfolio Committee, Dial Rock Hall, Saldanha, 22 March 2017). on this ecosystem is escalating and changes are taking place. Some negative influences have been ongoing for years and are unfortunately irreversible. One example is the Mediterranean mussel (Mytilus galloprovincialis), now the dominant low intertidal mussel on the West Coast, that was introduced through shipping activities from Europe in 1984 and even much earlier. The distribution of this exotic bivalve already extends over a large area stretching from the Namibian border to Port Alfred (Branch et al. 2005).

Negative ecological changes, through surveys executed over the last 30 years, provide important evidence, and examples include the long-term decreases in aquatic macrophytes (eelgrass and salt marshes) and certain bird species in Saldanha Bay and Langebaan Lagoon. This Ramsar area with its sheltered waters and abundance of prey has been identified as the most important wetland refuge for waders on the west coast of South Africa (Clark et al. 2016).

There are three distinct intertidal habitats that exist within Langebaan Lagoon, namely, seagrass beds (such as those of the eelgrass Zostera capensis), salt marsh (dominated by cordgrass Spartina maritime and Sarcocornia perennis) and unvegetated sandflats (dominated by the sand prawn, Callichirus kraussi and the mudprawn Upogebia capensis). The environments that eelgrass and salt marsh beds create, are of utmost importance in 


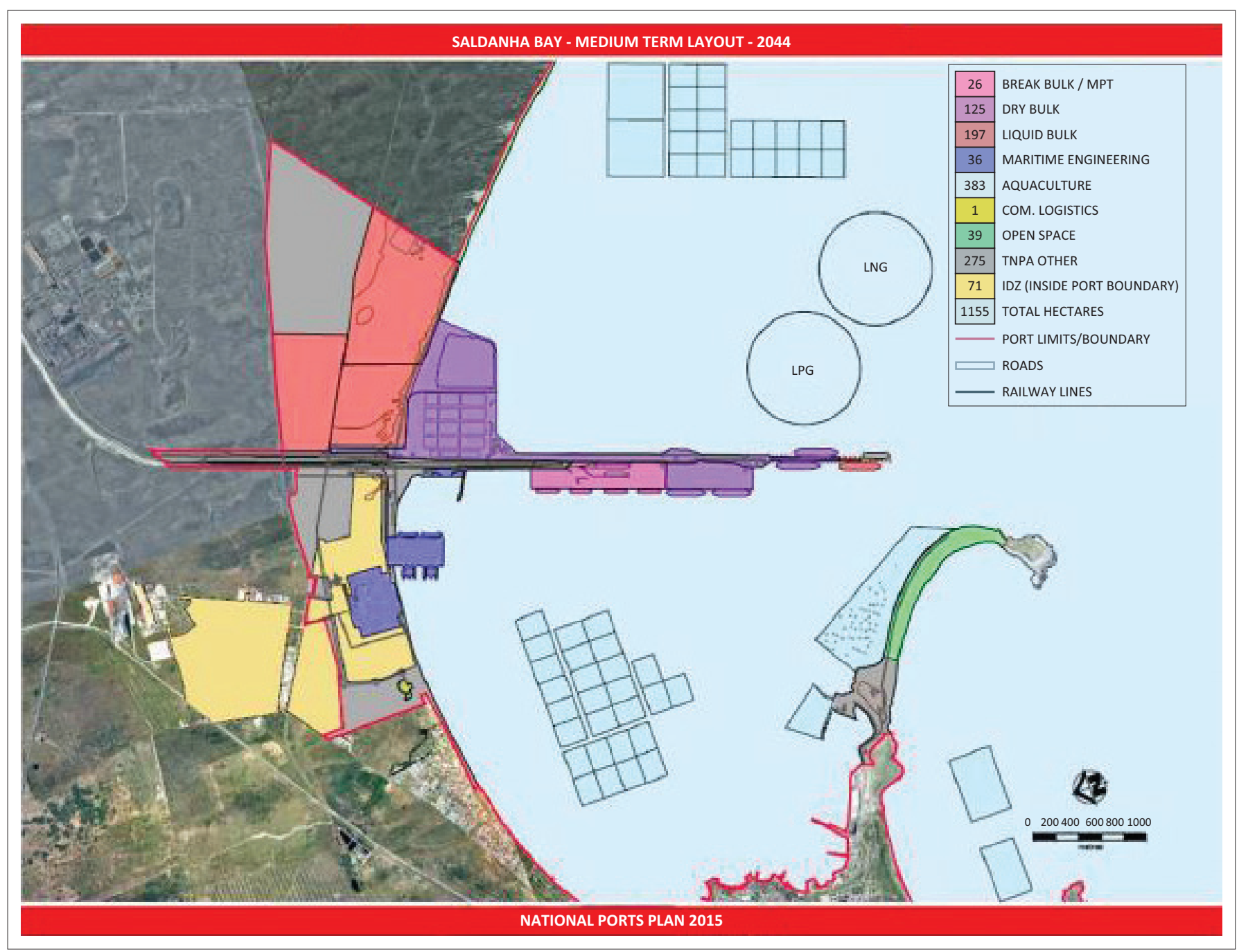

TNPA, Transnet National Port Authority.

Source: 'Sunrise Energy: 'n Nuwe Era', Weslander, 28 September, 2017b, p. 3

FIGURE 3: Transnet National Port Authority projected development in Saldanha.

the Langebaan Lagoon as they increase habitat diversity, act as an important food source, contribute to sediment stability and offer protection to juvenile fish and invertebrates from natural predators. In comparison with unvegetated areas, seagrass beds and salt marsh habitats support higher species richness, diversity, abundance and biomass of invertebrate fauna (Clark et al. 2016). Recent studies conducted by Clark et al. (2016) have shown that the aerial extent of seagrass beds in Langebaan Lagoon has declined by an estimated 38\% since the 1960s, this being more intense in some areas such as Klein Oesterwal where sea grass beds have declined by almost $99 \%$ over the same period. This decline in seagrass beds resulted in the associated benthic macrofauna becoming less abundant, whilst species that burrow primarily in unvegetated sand have increased in density. In contrast, little change occurred in the extent of salt marshes in Langebaan Lagoon, these having declined by no more than $8 \%$ since the 1960 s.

Declines in seagrass beds also influence the population strengths of wading birds and Clark et al. (2016) found a direct correlation between fluctuations in the abundance of the Terek Sandpiper (Xenus cinereus) and the availability of
Zostera beds. These birds feed exclusively in Zostera beds and their population declined drastically during periods of seagrass non-availability.

Other birds that have shown a downward trend in numbers since the 1980s are the African Penguin (Spheniscus demersus), Bank Cormorant (Phalacrocorax neglectus) and Palaearctic ${ }^{9}$ migratory birds. The African Penguin breeding populations decreased at all four islands in Saldanha Bay from 2001, with 2156 breeding pairs, till 2014 when only 314 breeding pairs were noted (Clark et al. 2016). There is no doubt that these developments are a great concern. Immediate national conservation action is required to prevent these birds becoming extinct. Bank Cormorant numbers in Saldanha Bay have declined by approximately $80 \%$ since 1990 . Breeding pairs dropped to as low as 22 pairs in 2013 but have since increased to 50 in 2014 (Clark et al. 2016). Since 1980, there has been a drastic decline in the numbers of Palaearctic visitors to the lagoon which is at least in part because of disturbances to their 9.The Palearctic is one of the eight ecozones subdividing the Earth's surface and includes the terrestrial eco-regions of Europe, Asia north of the Himalaya foothills, northern Africa, and the northern and central parts of the Arabian Peninsula. 


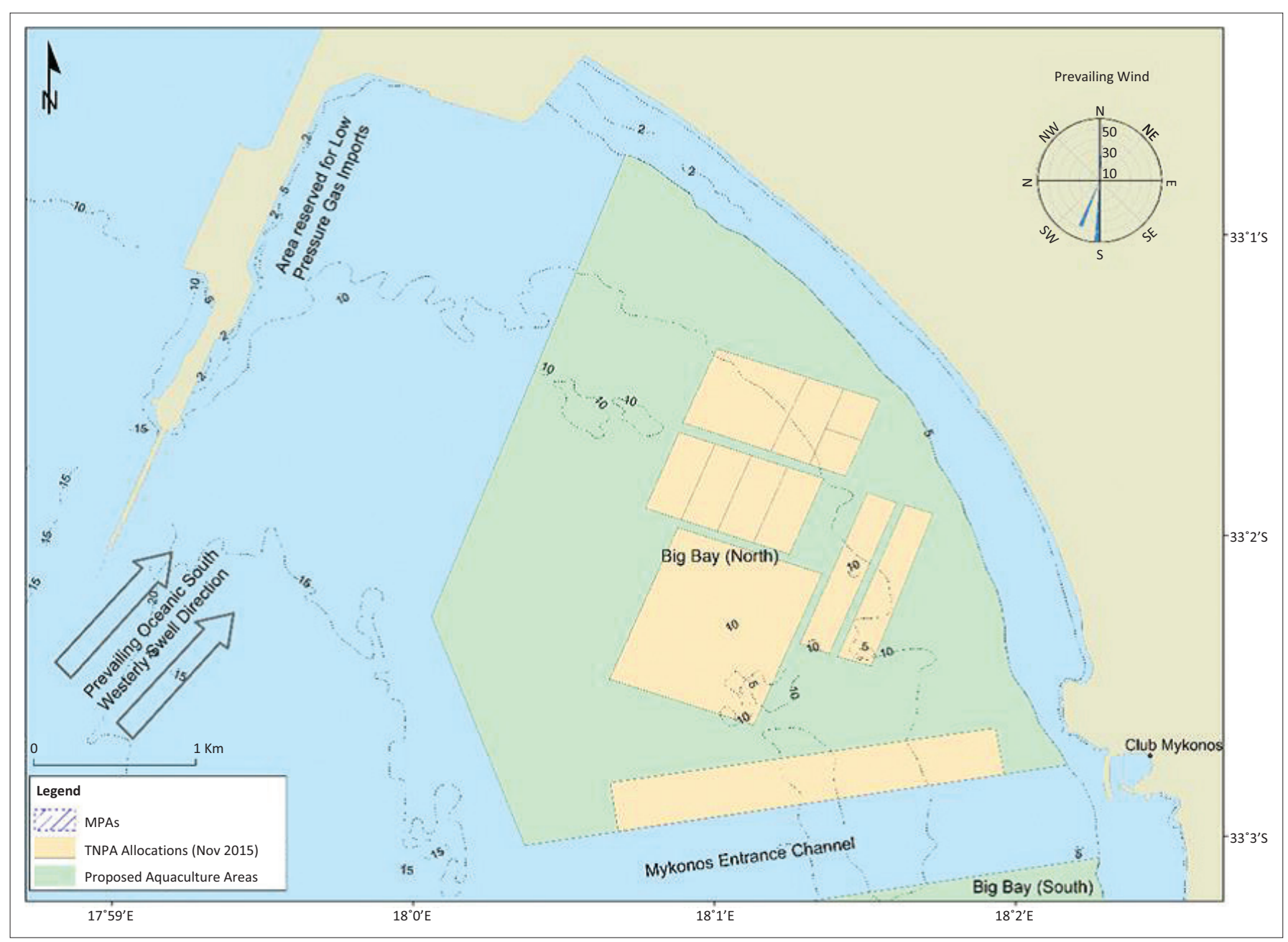

Source: CapMarine, 2016, Feasibility Assessment for a proposed sea-based aquaculture development zone in Saldanha Bay, Saldanha ADZ Key Stakeholder Workshop Presentation, Cape Town FIGURE 4: Proposed aquaculture development zones in Big Bay - North of Mykonos.

breeding grounds. More important, however, is that there has also been a dramatic decline in resident wader numbers, which is an indication of habitat changes and human influence that significantly disturb the ecological balance of the lagoon (Clark et al. 2016).

Potential or real threats that major industrial developments generate need mentioning. An excellent example of an unforeseen threat caused by industrial development is the continuing red dust phenomenon caused by the ArcellorMittal iron-ore plant. Unforeseen negative outcomes evolved into a major pollution problem with health risks for humans and animals and infrastructure damages (buildings and vehicles) alike. Concerning the present planned projects, the following early warnings or red lights stemming from our research should be mentioned:

- suboptimal planning for security measures and safety for the public such as roads that stretch close to storage facilities, for example, the gas facilities constructed adjacent to the Langebaan-Saldanha connecting route

- the potential for real pollution caused by dredging and oil or gas spills in the Engineering Hub and the obstruction dangers that anchor buoys, as well as underwater pipelines and overland pipelines hold.
Concerning the 884 ha sited for the Operation Phakisa aquaculture development, the following threats come to mind:

- The environmental authorisations sanctioning the fish and bivalve farming have been granted to the developers by DEA. This is the same government agency appointed as SA's Administrative Authority responsible for the implementation of the Ramsar Treaty provisions. Such a conflict of interest can conceivably negatively influence effective management and protection of the site as envisaged by the Ramsar Convention.

- The aquaculture developers plan to get operations to full production within a short 5 year period which is an insufficient window to respond to the accumulated impact and probable changes to the dynamics of the wetland. The complete impact may only manifest after the 10-year leases, which have been granted to aquaculture operators, have expired.

- Langebaan Lagoon is a shallow intertidal system that flushes out to sea only every 4 days. This poses a threat as accumulated waste matter can be transferred from the floating fish factories into the wetland system.

- The developers promote the aquaculture farms as an opportunity for job creation. However, the number of 


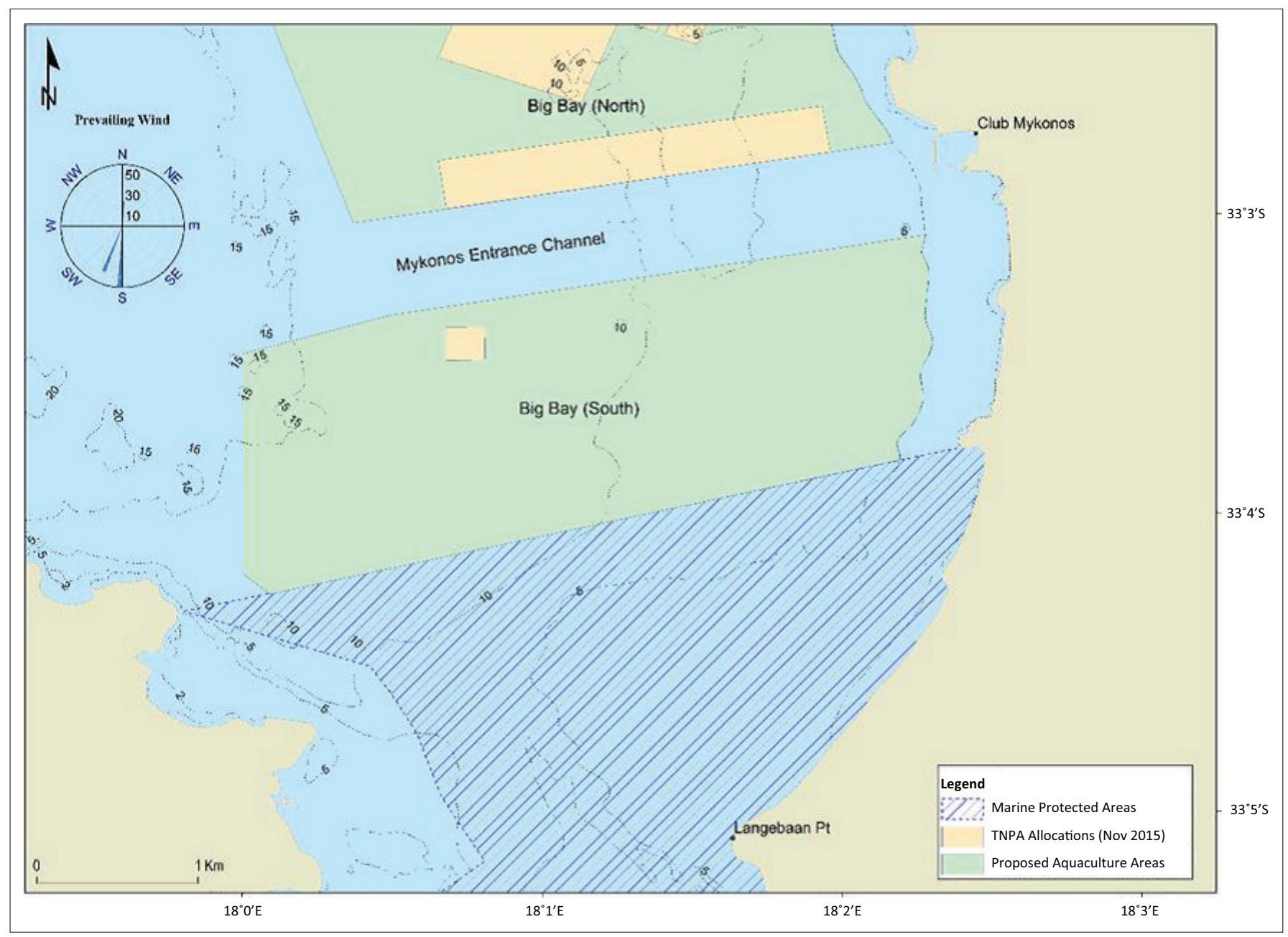

Source: CapMarine, 2016, Feasibility Assessment for a proposed sea-based aquaculture development zone in Saldanha Bay, Saldanha ADZ Key Stakeholder Workshop Presentation, Cape Town FIGURE 5: Proposed aquaculture development zones in Big Bay - South of Mykonos.

new jobs created by aquaculture over the next 5 to 10 years is insignificant in comparison with the current employment in the hospitality and tourism sectors of Langebaan. Both these areas of employment are likely to experience a severe collapse in the event of the Lagoon being adversely impacted because of aquaculture activities. The welfare of the communities who live around these water systems is dependent on the health and sustainability of this valuable resource.

- Recreational users of Saldanha Bay and Langebaan Lagoon will be influenced by the exclusion zones around the fish farms. Among the reasons why tourists interested in water sports and appreciation of the environment (i.e. divers and birdwatchers) may decline could be because of visual pollution, no-access days because of industrial activities, real or potential toxic contamination and the declining availability of space.

\section{Recommendations}

The only waters which are exclusively protected from human interference are situated within the military area borders. Activities in the military area waters are limited and in certain areas, such as parts of Riet Bay, access is prohibited even to military personnel, rendering these sensitive ecological features distinct protection status.

As seen from Figure 1, the border of the proclaimed Ramsar area, stretching from Perlemoen Point south of Riet Bay to Leentjiesklip, excludes the military area. The present formulation of the wetland, as described by Cowan (1995), should be revised and Meeuw Island, Donkergat Bay, Riet Bay and Salamander Bay should be so included. To embrace the island and bays, the Ramsar area border must stretch from Salamander Point north of Salamander Bay (Figure 6) to Leentjiesklip. The dimensions in hectare that each of these entities comprises are shown in Table 1.

The voluntary inclusion of these military areas into the formally recognised Ramsar site is possible. An earlier example is the precedent-setting expansion of the De Hoop Nature Reserve where a missile and weapons test range at the De Hoop rocket-testing facility in the Cape Overberg region exists (Cowan 1995). The present demarcation of Langebaan Lagoon as a Wetland of International Importance should be revised and the stipulation for the inclusion of the above-mentioned areas should be considered and 


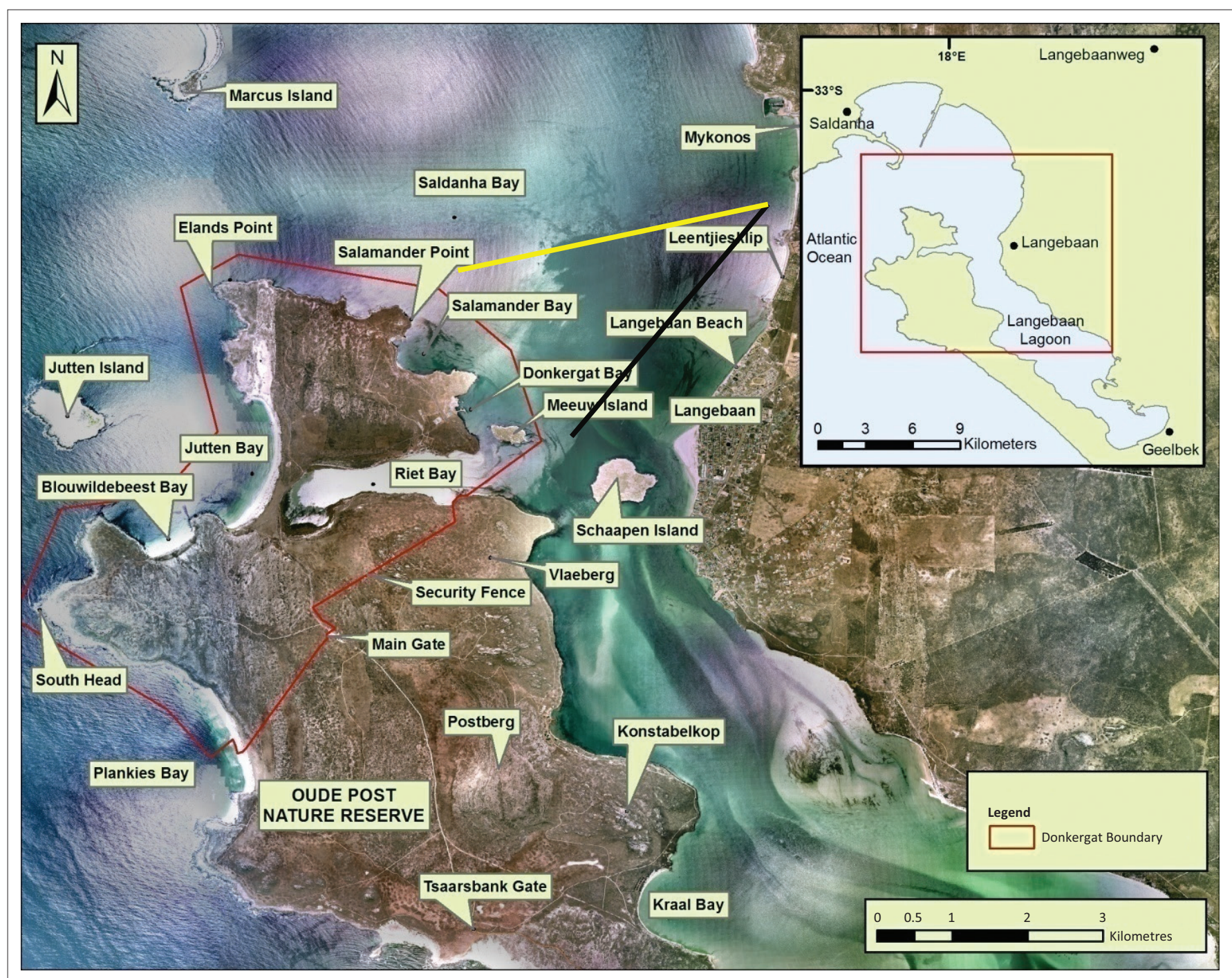

Source: Marx, J.T., 2014, 'Military integrated environmental management at the Donkergat Military Training Area', PhD dissertation, Stellenbosch University

Note: The peninsula (Schier Island) of Donkergat is formed by Riet Bay to the east on the Lagoon side and Jutten Bay to the west on the Atlantic Ocean. The military facility, infrastructure and training areas are concentrated on the peninsula and most training activities are executed here. Inset displays Saldanha and Langebaan regions. The proclaimed Ramsar area boundary is indicated by the black line above Schaapen Island and the proposed border in yellow from Salamander Point to Leentjiesklip.

FIGURE 6: Donkergat Military Training Area.

TABLE 1: Area sizes of regions of Donkergat Military Training Area to be included in the Langebaan Ramsar site.

\begin{tabular}{lc}
\hline Locality & Area (ha) \\
\hline Meeuw Island & 7 \\
Donkergat Bay & 39 \\
Riet Bay & 186 \\
Salamander Bay & 46 \\
\hline
\end{tabular}

Source: Marx, J.T., 2014, 'Military integrated environmental management at the Donkergat Military Training Area' PhD dissertation, Stellenbosch University

so appended. The suggested inclusions will amplify the environmental responsibility of the military, but on the contrary, give DMTA an international conservation status and add to the value of Meeuw Island and Riet Bay as 'sacred' areas. Although the entire DMTA coastline, from Salamander Bay in the north to Perlemoen Point in the south, borders on the designated Langebaan Lagoon Wetland, the suggested functional inclusion of Meeuw Island (7 ha), Donkergat Bay (39 ha), Riet Bay (186 ha) and Salamander Bay (46 ha) will expand the existing Ramsar area definition by a significant 278 ha (Figure 7). In addition, the waters south-east of the newly proposed Salamander Leentjiesklip Ramsar border, that was not part of the declared wetland, will be included.

According to the signatory criteria adopted at the Conference of Contracting Parties held in Montreux in 1990 (Cowan 1995), no major objections can be raised to the proposed DMTA area inclusion into the current Ramsar site. Such inclusion would compel the South African Department of Defence (DOD) to shoulder an increasingly significant responsibility in the conservation of the natural environment entrusted to its care - essentially thus to counter increasing pressure being placed on natural domains occurring in training areas of the DOD.

\section{Military Integrated Environmental Management}

The exclusive conservation value of DMTA necessitated scientifically founded management that resulted in the implementation of a MIEM plan (Marx 2014). One of the 


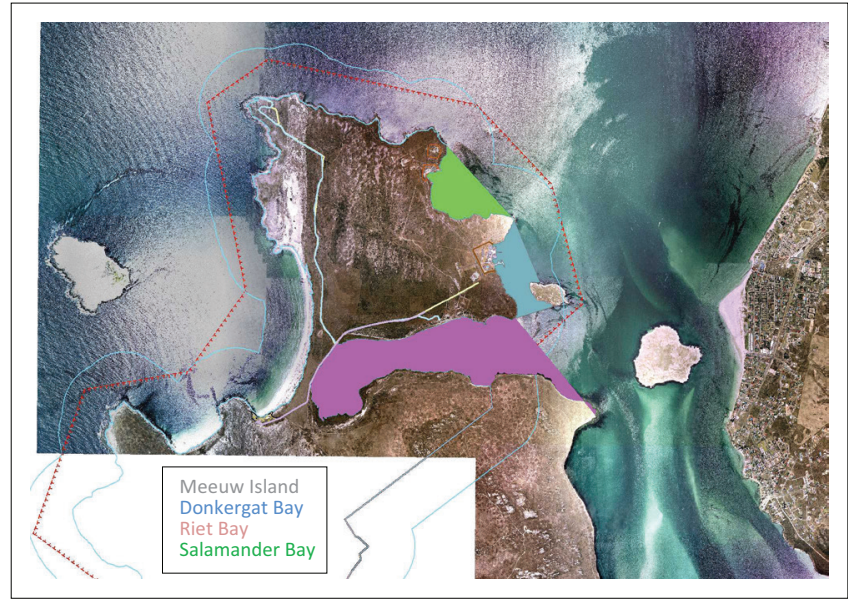

Source: Marx, J.T., 2014, 'Military integrated environmental management at the Donkergat Military Training Area', PhD dissertation, Stellenbosch University

FIGURE 7: Proposed localities to be included in the Langebaan Ramsar site.

purposes of the plan is to dictate that military activities are kept within the constraints of this sensitive area with sensible utilisation as the aim. If the designated military areas are included in the existing wetland, the MIEM approach will contribute to the conservation of the Langebaan Lagoon system as an entity. By practising sound management principles, criticism from members of the public can be proactively mitigated. Although DMTA is a restricted area, it must be emphasised that it is not exempted from the critical eye of the outside world and mismanagement will not go unnoticed.

\section{Conclusion}

A holistic approach in monitoring and assessing the overall health status of the Saldanha Bay must be implemented and regular monitoring of all parameters is essential. To date, most of the environmental impact studies have been localised without taking the entire Saldanha Bay, Langebaan Lagoon and Donkergat ecosystem into account. At DMTA, impact studies can be initiated by DOD personnel for the monitoring of ecosystem indicators such as bird surveys, water quality, sediment features, benthic macrofauna, surf-zone fish and rocky intertidal macrofauna.

By getting involved, the DMTA can play an increasingly important role as a reference tool to influence public decisionmakers of the Saldanha Bay area and become one of the ruling ecosystems against which development can be measured. The presence of absolute sacred areas with international conservation status, such as Meeuw Island and Riet Bay, will add to the value of DMTA as an ecological frame of reference. To succeed in assuring the survival of Donkergat, this military area must be managed and developed to act as the reference model for the bigger Saldanha Bay area and other DOD assets in South Africa.

\section{Acknowledgements}

This article is based on the PhD of Dr J.T. Marx. This is not a registered project per se.

\section{Competing interests}

The authors declare that they have no financial or personal relationships that may have inappropriately influenced them in writing this article.

\section{Authors' contribution}

This article is based on research conducted by Dr J.T. Marx during the course of his PhD. He completed the thesis at the Stellenbosch University (SU) in South Africa. This article is a spin-off from this extensive research undertaking. The second author (I.L.) provided some insights on government policy, socio-economic attitudes and developments, brief notes on local (social and/or military) history of the Saldanha Bay area and public attitudes. The second author contributed between $15 \%$ and $20 \%$ of the work done for this article.

\section{References}

Baradat, L.P., 2012, Political ideologies: Their origins and impact, Longman, Delhi.

Best, P.B., 2009, 'The whalers of Saldanha Bay', in G. Athiros, L. Athiros, N. Athiros \& M. Turner (eds.), A West Coast Odyssey: A journey into the history of the Cape's West Coast Peninsula, pp. 129-130, Historical Media, Tokai.

Best, P.B. \& Ross, J.B., 1989, 'Whales and whaling', in A.I.L. Payne \& R.J.M. Crawford (eds.), Oceans of life, pp. 315-338, Vlaeberg Publishers, Vlaeberg.

Branch, G.M., Branch, M.L., Griffiths, C.L. \& Beckley, L.E., 2005, Two oceans. A guide to the marine life of Southern Africa, David Phillip, Claremont, CA.

CapMarine, 2016, Feasibility Assessment for a proposed sea-based aquaculture development zone in Saldanha Bay, Saldanha ADZ Key Stakeholder Workshop Presentation, Cape Town, 16 September.

Clark, B.M., Massie, V., Hutchings, K., Laird, M., Biccard, A., Brown, E. et al., 2016, The State of Saldanha Bay and Langebaan Lagoon 2016, (Technical Report. Report No. AEC 1691/1) prepared by Anchor Environmental Consultants (Pty) Ltd for the Saldanha Bay Water Quality Forum Trust.

Cowan, G.I., 1995, 'South Africa and the Ramsar convention', in J. Cowan (eds.) Wetlands of South Africa, pp. 1-20, Department of Environmental Affairs and Tourism, Pretoria.

DEAT, 2005, Environmental assessment of international agreements, Integrated Environmental Management Information Series 19, Department of Environmental Affairs and Tourism, Pretoria.

De Graaff, G. \& Randall, R., 1987, Langebaan Lagoon Ramsar Designation, Nationa Parks Board of Trusters, Pretoria, viewed 30 August 2017, from https://rsis. ramsar.org/398.

Department of Environmental Affairs, 2012, 2nd South Africa Environment Outlook A report on the state of the environment. Executive Summary, Department of A report on the state of the envir
Environmental Affairs, Pretoria.

Ecosense Consultants, 2017, Basic assessment report for the proposed Molapong Aquaculture Project, Saldanha Bay. DEA\&DP Reference No: 16/3/3/1/F4/17/ 3014/17, July 2017.

Ervik, A., Hansen, P.A., Aure, J., Stigebrandt, A., Johannessen, P. \& Jahnsen, T., 1997 'Regulating the local environmental impact of intensive marine fish farming I. The concept of the MOM system (Modelling - On growing fish farms - Monitoring)' Aquaculture 158, 85-94. https://doi.org/10.1016/S0044-8486(97)00186-5

Fernandes, T.F. \& Read, P.A., 2001, 'Aquaculture and the management of coastal zones', in P.A. Read, T.F. Fernandes, K.L. Miller, A. Eleftheriou, I.M. Davies \& G.K. Rodger (eds.), The implications of directives, conventions and codes of practice on the monitoring and regulation of Marine Aquaculture in Europe Proceedings of the Second MARAQUA Workshop 20-22 March, 2000, Institute of Marine Biology, Crete, Scottish Executive Aberdeen, UK, pp. 75- 83.

GESAMP (IMO/FAO/UNESCO-IOC/WMO/WHO/IAEA/UN/UNEP Joint Group of Experts on the Scientific Aspects of Marine Environmental Protection), 2001, Planning and management for sustainable coastal aquaculture development, Rep. Stud. GESAMP No. 68., Rome, Italy, 90 pp.

Heywood, A., 2007, Political ideologies: An introduction, 4th edn., Palgrave Macmillan, Hampshire.

'Latest on Saldanha bay IDZ', Weslander, 28 September, 2017a, p. 7.

Marx, J.T., 2009, 'The whaling timeline of the Cape', in G. Athiros, L. Athiros, N. Athiros $\&$ M. Turner, (eds.), A West Coast Odyssey: A journey into the history of the Cape's West Coast Peninsula, 135 p, Historical Media, Tokai.

Marx, J.T., 2014, 'Military integrated environmental management at the Donkergat Military Training Area', PhD dissertation, Stellenbosch University.

McLean, S., 2009, 'Darling Airfield in World War II', in G. Athiros, L. Athiros, N. Athiros \& M. Turner (eds.), A West Coast Odyssey: A journey into the history of the Cape's West Coast Peninsula, pp. 145-146, Historical Media, Tokai. 
Mouton, J. \& Marais, H.C., 1996, Basic concepts in the methodology of the socia sciences, Human Sciences Research Council, Pretoria.

Mulaudzi, M. \& Liebenberg, L, 2017, 'Planning and socio-economic intervention in developmental state: The case of South Africa', Journal of Public Administration 52(1), 29-34.

O'Callaghan, M., 1990, 'Salt marshes - A very specialised environment', Custos 18 58-60.

Ramsar Sites Information Service, 2017, Annotated list of wetlands of internationa importance, South Africa, viewed 30 August 2017, from http://www.ramsar.org/ wetland/south-africa

South Africa (Republic of), 1979a, Government Gazette, vol. 457, 9 March, No 4331 Government Printer, Pretoria.

South Africa (Republic of), 1979b, Government Gazette, vol. 6216, 17 November No 2304, Government Printer, Pretoria.

South Africa (Republic of), 1985, Langebaan Lagoon, Saldanha Bay islands and Atlantic shore proclaimed as national park i.t.o section 2 (2) of the National Parks Act 1976, Government Gazette, vol. 10035, 13 December, Notice 2773, Government Printer, Pretoria.
South Africa (Republic of), 1987, Postberg properties proclaimed a contractual park of the park i.t.o section 2B (1) (b) of the National Parks Act, 1976, Government the park i.t.o section $2 B$ (1) botice 1385, Government Printer, Pretoria.

South Africa (Republic of), 1998, National Environmental Management Act, Act 107 of 1998, Government Printer, Pretoria.

South Africa (Republic of), 2001, First edition environmental implementation plan for defence, Government Gazette, Volume 22022, 16 February, Notice 249. Pretoria: Government Printer.

Spring, I., 1995, Flying boat, Henkos Printers, Pretoria.

SRK Consulting, 2017, Proposed Sea-Based Aquaculture Development Zone in Saldanha Bay, Final Basic Assessment Report, Report Prepared for Department of Agriculture, Forestry and Fisheries, Cape Town, Report Number 499020 / 05 August 2017.

'Sunrise Energy: 'n Nuwe Era', Weslander, 28 September, 2017b, p. 3.

The Montreux Record, 2011, List of Wetlands of International Importance included in the Montreux Record, viewed 02 October 2017, from http://archive.ramsar.org/ cda/en/ramsar-documents-montreux-montreux-record/main/ramsar

World Bank, 1996, International agreements on environment and natural resources: Relevance and application in environmental assessment, The World Bank, Washington, DC 